\title{
Research Article \\ In-vitro antidiabetic activity of methanolic extract of leaves and fruits of Pouteria campechiana (Kunth) Baehni
}

\author{
Akshata Pai ${ }^{1}$, Chandrakala Shenoy K. ${ }^{2}$ \\ ${ }^{1}$ Research Scholar, ${ }^{2}$ Professor, Department of Biosciences, Mangalore University, Mangalagangothri, Mangalore- 574 199, \\ Karnataka, India
}

(Received: June 2021

Revised: August 2021

Accepted: October 2021)

Corresponding author: Chandrakala Shenoy K. Email: chandrakalashenoy2020@gmail.com

\begin{abstract}
Introduction and Aim: Herbal medicine have been used to treat several ailments since decades. Pouteria campechiana (Kunth) Baehni belongs to the family Sapotaceae which is widely found around the world. In folk medicine, various parts of $P$. campechiana is used to treat various illness. Inhibition of alpha-amylase and alphaglucosidase enzymes can be an important strategy in management of postprandial blood glucose level in non-insulin dependent diabetic patient. Hence, present study focused to evaluate the in vitro antidiabetic activity of leaf and fruit methanolic extract of Pouteria campechiana (Kunth) Baehni.
\end{abstract}

Materials and Methods: Methanolic extract of P. campechiana leaf (PCL) and fruit (PCF) was screened by biochemical assay such as $\alpha$-amylase inhibition activity by CNPG3 method (2-chloro-p-nitrophenyl- $\alpha$-Dmaltotrioside) and $\alpha$-glucosidase inhibition activity and in vitro cellular assay such as glucose uptake assay in 3T3L1 cell line.

Results: Methanolic extract of $P$. campechiana leaf and fruit showed inhibition of $\alpha$-Amylase and $\alpha$-Glucosidase enzymes. The methanolic extract of $P$. campechiana leaf and fruit at varying concentrations $(\mu \mathrm{g} / \mathrm{ml})$, did not exhibit cytotoxicity against 3T3-L1 cell line after 24 hours of incubation. The test compounds PCL and PCF induced the uptake of 2-(N-(7-Nitrobenz-2-oxa-1,3-diazol-4-yl) Amino) - 2-Deoxyglucose (2-NBDG) in 3T3L1 cells. PCF and PCL both showed almost similar activity of standard drug, Metformin at higher concentrations.

Conclusion: Based on the results, it can be concluded that methanolic leaf and fruit extract of $P$. campechiana possess antidiabetic activity.

Keywords: Pouteria campechiana; alpha amylase; alpha glucosidase; 3T3-L1 cell line.

\section{INTRODUCTION}

$\mathrm{D}$ iabetes mellitus (DM) is a metabolic disorder characterized by a chronic hyperglycemia with dysregulation of carbohydrates, fats, and protein metabolism resulting from defective secretion and function of insulin (1). Diabetes mellitus is also characterized by a reduced reaction of insulinsensitive peripheral tissues and a marked decrease in glucose uptake and metabolism in response to insulin. Rapid development and progression of Type 2 DM has been evolved from past few decades. Its main cause is progressively reduced insulin secretion by pancreatic $\beta$-cells of pre-existing insulin resistance in skeletal muscle, liver and adipose tissue (2).

Genus Pouteria is a tropical fruit trees belonging to the family Sapotaceae. The Pouteria species was reported to possess many biologically active polyphenolic antioxidants including gallic acid, (+)-gallocatechin, $(+)$-catechin, (-)-epicatechin, dihydromyricetin, (+)catechin-3-O-gallate, and myricitrin (3). GC-MS analysis of methanolic extract of $P$. campechiana leaf and fruit possess many phytoconstituents such as chinasaure, aspidocarpine, octadecanoic acid methyl ester, dibutyl phthalate, 11,14,17-eicosatrienoic acid methyl ester, and phytol acetate, acetic acid, pentyl ester, glycerine, 4H-Pyran-4-one, 2,3-dihydro3,5dihydroxy-6-methyl, DL-arabinitol, 3-deoxy-dmannoic lactone, d-glycero-d-tallo-heptose, and stigmast-5-en-3-ol, (3ß) (4). The leaves are reported to be anti-inflammatory. Bark decoction of $P$. campechiana is used as an antipyretic in Mexico as well as to treat skin eruptions in Cuba. The fruit of $P$. campechiana is reported as a rich source for carotenoids and is well known as an antioxidant and a hepatoprotective (5).

Inhibition of the $\alpha$-amylase should reduce the unfavourable high postprandial blood glucose peak in diabetics. Intestinal $\alpha$-glucosidase inhibitors are reported to be powerful therapeutic agents in carbohydrate metabolic disorders, especially diabetes mellitus and obesity (6). To control post-prandial hyperglycemia with non-insulin-dependent diabetes mellitus (NIDDM), biguanides such as metformin are used for the enhancement of glucose uptake by peripheral cells stimulation of basal glucose transport and metabolism in muscle and fat cells would explain increased glucose utilization. Therefore, cellular assays are used to determine the mechanism of action of natural or synthetic compounds from isolated rat diaphragms, as well as isolated and cultured rat 3T3 adipocytes. Hence, it is highly desirable to find new 
antidiabetic agents from natural resources that stimulate glucose uptake by peripheral tissues such as adipose tissue or muscle cells (7). In this study, we evaluated the antidiabetic properties of $P$. campechiana leaf and fruit extract in vitro using the 3T3-L1 as a model system.

\section{MATERIALS AND METHODS}

\section{Collection of plant material}

$P$. campechiana leaves and fruit were collected from Bellikoth, Kasargod District, Kerala. The plant material was verified and authenticated in the Department of Botany, Kerala University, Kariavattom. The voucher specimens were preserved in the herbarium library in botany department (Accession no: KUBH 10170) (4). The fresh leaves and fruits of the plant $P$. campechiana were collected, shade dried, powdered mechanically and stored at $4^{\circ} \mathrm{C}$ for further studies.

\section{Preparation of plant extract}

The extraction was carried out by the continuous hot percolation method in a Soxhlet apparatus using methanol. The methanolic extract obtained were concentrated to dryness using the rotary vacuum evaporator, dried and stored in airtight bottles in a refrigerator at $4^{\circ} \mathrm{C}$ for further use.

\section{$\alpha$-Amylase inhibitory assay}

The assay for inhibition of $\alpha$-amylase was carried out as described by Kumar et al., (8) with slight modification. The enzyme solution was prepared by mixing $\alpha$-amylase $(3.246 \mathrm{mg}$ ) in $100 \mathrm{ml}$ of $40 \mathrm{mM}$ phosphate buffer ( $\mathrm{pH}$ 6.9). A positive control was prepared by dissolving acarbose in phosphate buffer and diluted to get a various concentration using phosphate buffer ( $\mathrm{pH}$ 6.9). P. campechiana leaf and fruit extract was dissolved in phosphate buffer to give final concentrations of $37.5,75,150,300,600$ and $1200 \mu \mathrm{g} / \mathrm{ml}$. The acarbose and plant extract were mixed with 2-Chloro-4-Nitrophenol $\alpha$-DMaltotrioside (CNPG3) and incubated for $8 \mathrm{~min}$ at $37^{\circ} \mathrm{C}$. Reaction was arrested by heating on boiling water bath for $2 \mathrm{~min}$ and cooled. The absorbance was read at $405 \mathrm{~nm}$. A control reaction was prepared without the plant extract/acarbose and measured in a similar manner.

Percentage inhibition $=\frac{\text { Mean OD }}{(\text { Control) }}-$ Mean OD $_{\text {(Test) }}$
Mean OD
$\boldsymbol{\alpha}$-Glucostrol)

The $\alpha$-glucosidase inhibitory activity was measured as described by Dayananda et al., (9). Reaction mixture consisted of crude enzyme solution $(50 \mu \mathrm{l})$, sucrose $(37 \mathrm{mM}, 500 \mu \mathrm{l})$ in $80 \mathrm{mM}$ potassium phosphate buffer $(\mathrm{pH} \mathrm{7.0})$, and the test sample $(1 \mathrm{mg} / \mathrm{ml})$ in dimethyl sulfoxide (DMSO) and diluted to get various concentrations $3.125,6.25,12.5,25,50$ and 100 $\mu \mathrm{g} / \mathrm{ml}$. After incubation for $20 \mathrm{~min}$ at $37^{\circ} \mathrm{C}$, the reaction was stopped by heating on boiling water bath for $2 \mathrm{~min}$. The amount of liberated glucose was measured by the glucose oxidase method.

Percentage inhibition $=\frac{\text { Mean OD }(\text { Control) }- \text { Mean OD }(\text { Test) }}{\text { Mean OD }(\text { Control) }} \times 100$

\section{Cell culture}

The murine 3T3-L1 cell line was procured from the National Centre for Cell Science, Pune. Cells were maintained in Dulbecco's Modified Eagle Medium (DMEM) (high glucose) with 10\% FBS (Invitrogen, Canada), 10,000 U Penicillin G, streptomycin sulfate $(10,000 \mu \mathrm{g} / \mathrm{ml})$ (Invitrogen), and $10 \mathrm{mM}$ 4-(2-hydroxyethyl) -1-piperazineethane sulfonic acid. Cultures were maintained at $37^{\circ} \mathrm{C}$ in $5 \%$ $\mathrm{CO}_{2}$ in a humidified incubator.

\section{In vitro cytotoxicity assay}

The Cell viability of 3T3-L1 cells was determined using 3- (4, 5-dimethylthiazol-2-yl) -2, 5- diphenyl tetrazolium bromide (MTT) assay (10). Cytotoxicity assay is a colorimetric assay to determine the noncytotoxic concentration of $P$. campechiana leaf (PCL) and fruit $(\mathrm{PCF})$ after $24 \mathrm{~h}$ exposure period based on the conversion of MTT to formazan crystals by the lactate dehydrogenase present in live cells. 3T3-L1 cells (200 $\mu \mathrm{l}$ cell suspension) were seeded in a 96-well plate at required cell density $(20,000$ cells per well), without the test agent. Cells were allowed to grow for about 24 h. Cells were then treated with different concentrations $10,20,40,80,160,320 \mu \mathrm{g} / \mathrm{ml}$ of leaf and fruit extract. Then the plates were incubated for $24 \mathrm{~h}$ at $37^{\circ} \mathrm{C}$ in a $5 \% \mathrm{CO}_{2}$ atmosphere. After the incubation period, plates were taken out from the incubator and spent media was removed. MTT reagent to a final concentration of $0.5 \mathrm{mg} / \mathrm{ml}$ of total volume was added and further incubated for $3 \mathrm{~h}$ at $37^{\circ} \mathrm{C}$. After incubation, MTT reagent was taken out and formazan crystals were dissolved with $100 \mu \mathrm{l}$ of DMSO, solubilisation solution. Absorbance was measured at $570 \mathrm{~nm}$ on ELISA reader. Percentage viability was determined using the formula:

Percentage of viability $=\frac{\text { Mean OD }_{\text {(Test) }} \text { at } 570 \mathrm{~nm}}{\text { Mean OD }(\text { untreated cells) at } 570 \mathrm{~nm}} \times 100$

\section{Glucose uptake assay}

3T3-L1 cell line were cultured in 6-well plate at a density of $2 \times 10^{5}$ cells $/ 2 \mathrm{ml}$ and incubated in ${\mathrm{a} \mathrm{CO}_{2}}$ incubator overnight at $37^{\circ} \mathrm{C}$. After $24 \mathrm{~h}$, spent medium was removed through aspiration and cells were treated with extract $(40 \mu \mathrm{g} / \mathrm{ml}$ and $320 \mu \mathrm{g} / \mathrm{ml})$ and controlmetformin $(100 \mathrm{uM})$. The extract and control were prepared of 2-NBDG and the cells were incubated for $2 \mathrm{~h}$. After $2 \mathrm{~h}$ of incubation, cells were washed with PBS. For adherent cells, PBS was removed and $200 \mu 1$ trypsin was added and incubated at $37^{\circ} \mathrm{C}$ for $3-4 \mathrm{~min}$. $2 \mathrm{ml}$ of culture medium was added and the cells were harvested directly into in $12 \times 75 \mathrm{~mm}$ tubes. Tubes were centrifuged and pellet was re-suspended in 0.5-1 
$\mathrm{ml}$ of PBS. Cellular uptake of 2-NBDG was analysed with a flow cytometer (11).

\section{Statistical analysis}

All experiments were performed in triplicates and results were expressed as mean percentage inhibition \pm standard deviation (SD) $(\mathrm{n}=3)$. $\mathrm{IC}_{50}$ values in enzyme inhibition assays were determined using linear regression graph (concentration versus percentage enzyme inhibition). All statistical analyses and IC50 values determination were carried out in GraphPad Prism (version 3.1) software (San Diego, CA).

\section{RESULTS}

\section{Inhibition of $\alpha$-amylase activity}

Percentage inhibition of $\alpha$-amylase activity by $P$. campechiana leaf and fruit extract was estimated with

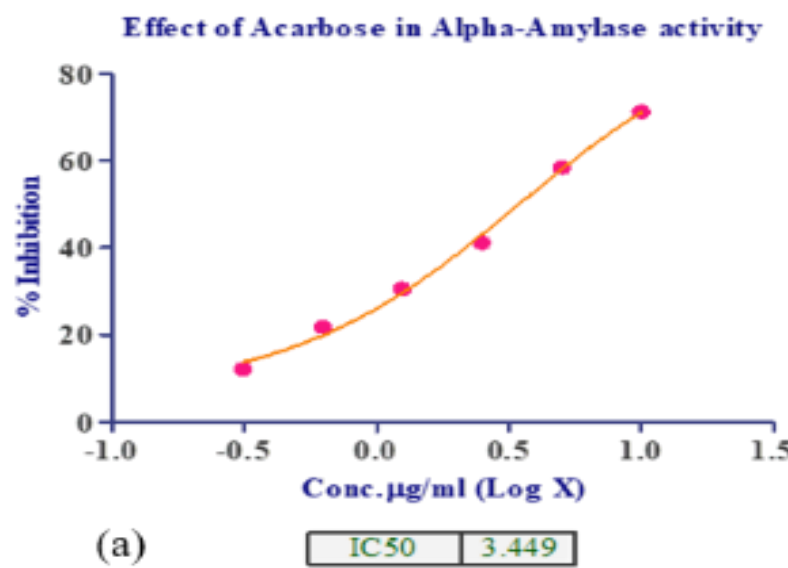

acarbose as positive control. The PCL and PCF extract showed $10.31 \pm 1.06 \%$ and $11.49 \pm 2.35 \%$ inhibition of $\alpha$-amylase activity at $37.5 \mu \mathrm{g} / \mathrm{ml}$ and $66.93 \pm 1.16 \%$ and $56.75 \pm 1.47 \%$ inhibition at $1200 \mu \mathrm{g} / \mathrm{ml}$ concentration respectively. The $\mathrm{IC}_{50}$ value of PCL and PCF extract was found to be $516.4 \mu \mathrm{g} / \mathrm{ml}$ and 927.4 $\mu \mathrm{g} / \mathrm{ml}$. The standard drug acarbose exhibited $12.14 \pm$ $0.53 \%$ inhibition of $\alpha$-amylase activity at 0.3125 $\mu \mathrm{g} / \mathrm{ml}$ and $71.30 \pm 1.30 \%$ inhibition at $10 \mu \mathrm{g} / \mathrm{ml}$ concentration. The $\mathrm{IC}_{50}$ value for acarbose was found to be $3.449 \mu \mathrm{g} / \mathrm{ml}$. The percentage inhibition of $\alpha$-amylase activity by the extract and drug at different concentrations represented in Figure 1.

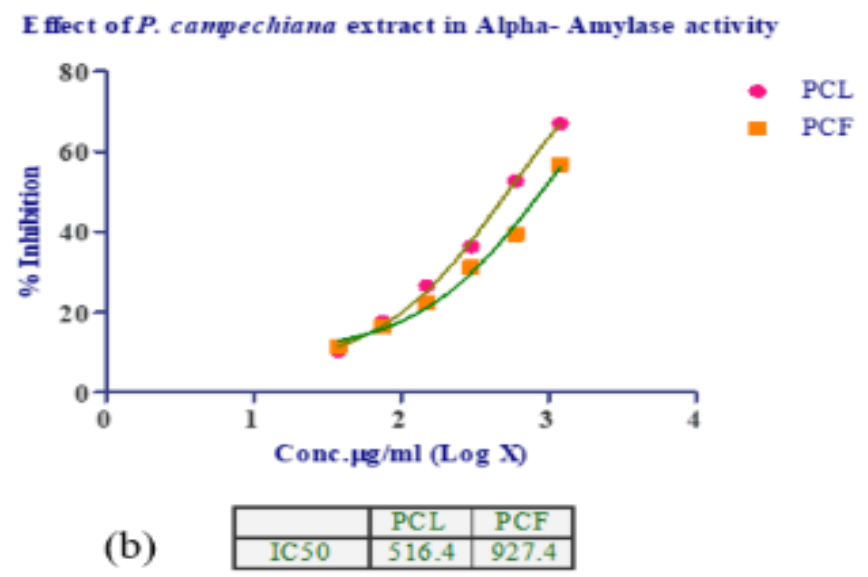

Fig. 1: Percentage inhibition of $\alpha$-amylase (a) Effect of acarbose (Standard) in $\alpha$-amylase activity (b) Effect of P. campechiana leaf (PCL) and fruit (PCF) methanolic extracts in $\alpha$-amylase activity. The values are represented in mean \pm SD in triplicates.

\section{Inhibition of $\alpha$-glucosidase activity}

Percentage inhibition of $\alpha$-glucosidase activity by $P$. campechiana leaf and fruit extract was estimated with acarbose as positive control. Methanolic extract of PCL and PCF showed significant inhibition of $\alpha$-Glucosidase activity. The lowest concentration of the leaf and fruit extract showed $9.24 \pm 1.70 \%$ and $10.23 \pm 1.93 \%$ inhibition respectively and the highest

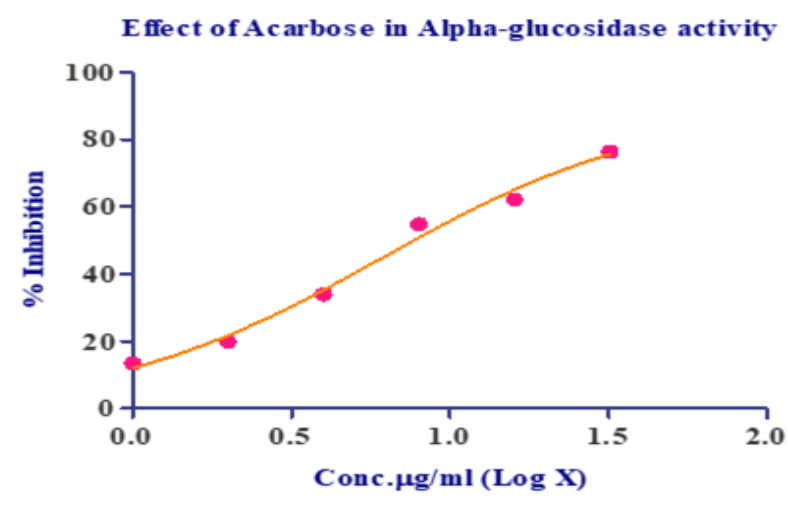

(a) concentration showed $58.67 \pm 1.01 \%$ and $67.75 \pm$ $1.35 \%$ of inhibition in $\alpha$-Glucosidase activity respectively. Acarbose, the positive control drug, showed a percent inhibition, in $\alpha$-Glucosidase activity, of $13.45 \pm 0.87 \%$ at $1 \mu \mathrm{g} / \mathrm{ml}$ and $76.38 \pm 0.50 \%$ at 32 $\mu \mathrm{g} / \mathrm{ml}$. The IC50 values of acarbose, PCL and PCF extract were found to be $6.11 \mu \mathrm{g} / \mathrm{ml}, 62.68 \mu \mathrm{g} / \mathrm{ml}$ and $45.03 \mu \mathrm{g} / \mathrm{ml}$, respectively, as shown in Figure 2 .

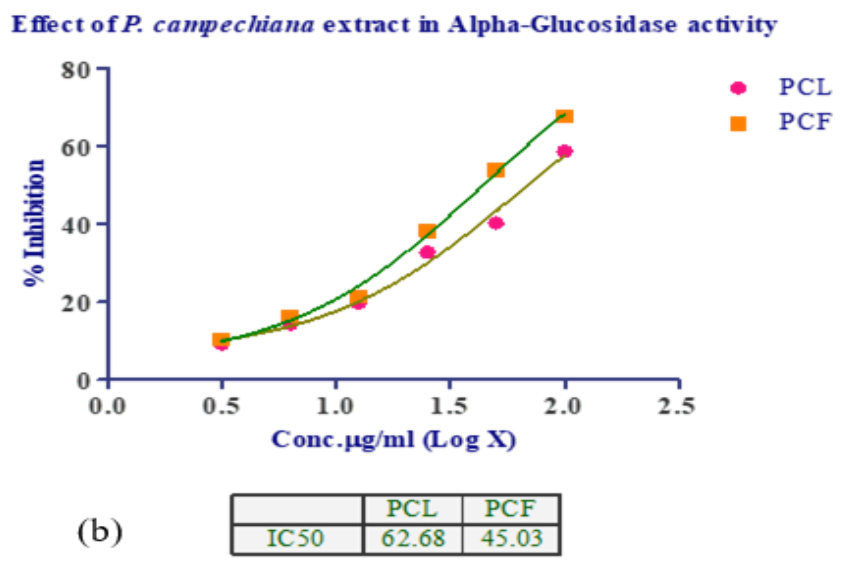

Fig, 2: Percentage inhibition of $\alpha$-glucosidase (a) Effect of acarbose (Standard) in $\alpha$-glucosidase activity (b) Effect of $P$. campechiana leaf (PCL) and fruit (PCF) methanolic extracts in $\alpha$-glucosidase activity. The values are represented as mean \pm SD in triplicates. 


\section{Cytotoxicity of $P$. campechiana leaf and fruit extract on $3 T 3 \mathrm{~L} 1$ cell line}

3T3-L1 cells were treated with different concentrations (10-320 $\mu \mathrm{g} / \mathrm{ml})$ of $P$. campechiana extract and were assayed for their cytotoxic effect. The extract had no cytotoxic effect on the cells. The concentrations of the extract used and the respective percent cell viability were tabulated and plotted in table 1 and figure 3 . The lowest concentration of PCL and PCF extract $(10 \mu \mathrm{g} / \mathrm{ml})$ showed $99.72 \pm 0.84 \%$ and $99.48 \pm 0.15 \%$ viability respectively, and the highest concentration $(320 \mu \mathrm{g} / \mathrm{ml})$ showed $102.21 \pm$ $0.37 \%$ and $101.79 \pm 0.46 \%$ of viability, respectively after $24 \mathrm{~h}$ of exposure. These results indicated that methanolic extract of PCL and PCF is not toxic to mammalian cells even at higher concentrations and could be used to analyze other parameters of in vitro antidiabetic studies.

Table 1: Cell viability of 3T3-L1 cells treated with different concentrations of methanolic extract of $P$. campechiana and $100 \mu \mathrm{M}$ of control drug

\begin{tabular}{|c|c|c|}
\hline \multirow{2}{*}{ Concentrations } & \multicolumn{2}{|c|}{ Percentage of cell viability } \\
\cline { 2 - 3 } & P. campechiana Leaf $(\mathbf{P C L})$ & $\boldsymbol{P}$. campechiana Fruit (PCF) \\
\hline Control (Untreated cells) & $100 \pm 0$ & $100 \pm 0$ \\
\hline $\mathbf{1 0} \boldsymbol{\mu g} / \mathbf{m l}$ & $99.72 \pm 0.84$ & $99.48 \pm 0.15$ \\
\hline $\mathbf{2 0} \boldsymbol{\mu g} / \mathbf{m l}$ & $99.95 \pm 0.86$ & $99.90 \pm 0.42$ \\
\hline $\mathbf{4 0} \boldsymbol{\mu g} / \mathbf{m l}$ & $100.99 \pm 1.07$ & $100.66 \pm 0.45$ \\
\hline $\mathbf{8 0} \boldsymbol{\mu g} / \mathbf{m l}$ & $101.27 \pm 1.07$ & $101.03 \pm 0.43$ \\
\hline $\mathbf{1 6 0} \boldsymbol{\mu} \mathbf{g} / \mathbf{m l}$ & $101.65 \pm 1.01$ & $101.18 \pm 0.43$ \\
\hline $\mathbf{3 2 0} \boldsymbol{\mu g} / \mathbf{m l}$ & $102.21 \pm 0.37$ & $101.79 \pm 0.46$ \\
\hline
\end{tabular}

Valúes are mean of triplícate determination $(n=3) \pm S D$

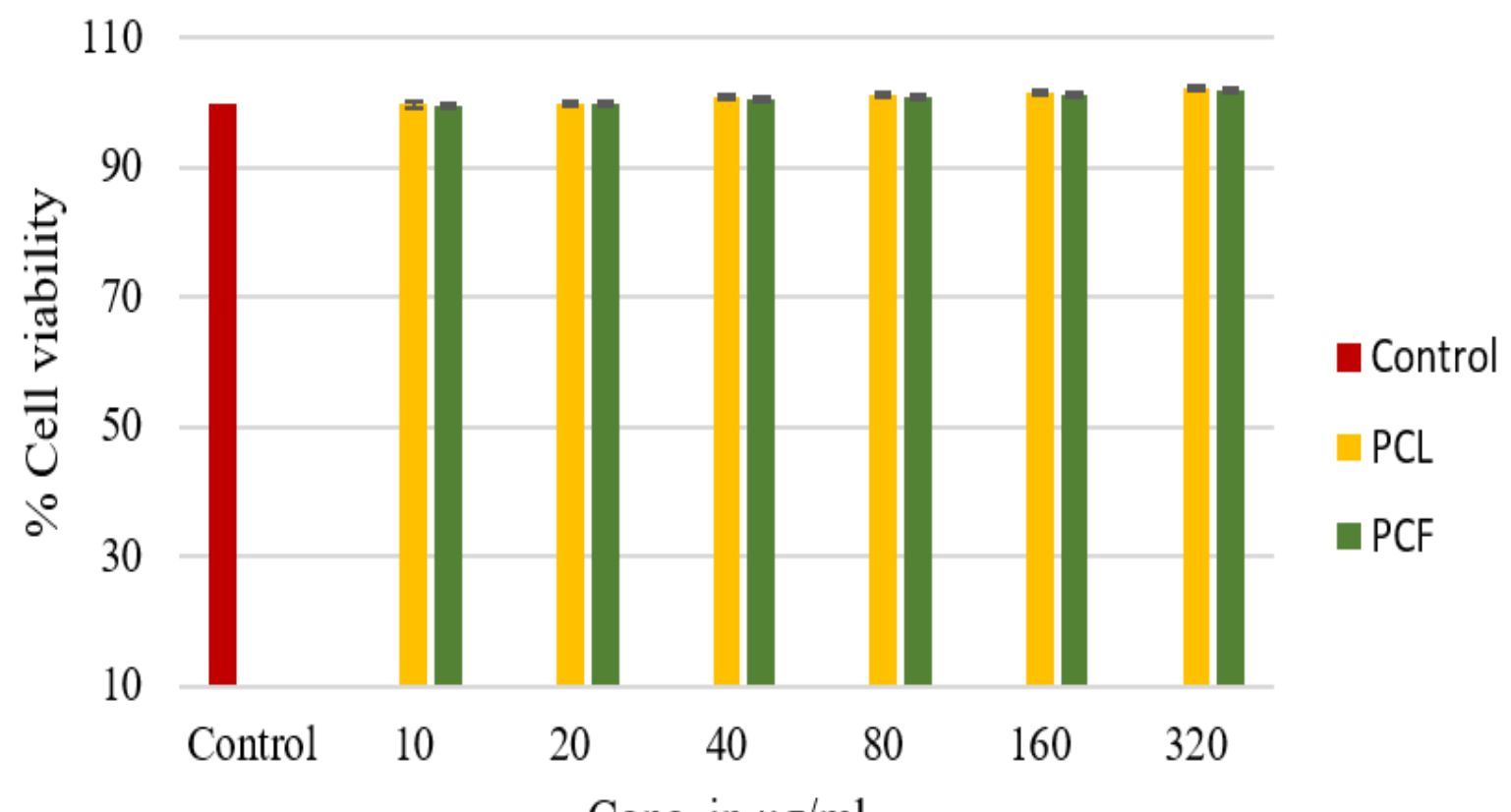

Conc. in $\mu \mathrm{g} / \mathrm{ml}$

Fig. 3: The effect of $P$. campechiana leaf and fruit extract on 3T3- L1 cell line viability as determined by 3-(4, 5dimethylthiazol-2-yl)-2, 5-diphenyltetrazolium bromide assay, after $24 \mathrm{~h}$ of incubation with various concentrations of the extract ranging from 10, 20, 40, 80, 160 and $320 \mu \mathrm{g} / \mathrm{ml}$. Each bar represents the data as the mean \pm standard deviation of triplicate experiments.

\section{Glucose uptake assay}

2-NBDG, a fluorescent deoxyglucose analog, was used as probe for the cellular uptake of glucose in 3T3-L1 cells. The results showed that the percentage of cells taken up 2-NBDG were higher in the population of cells treated with lower and higher concentration of $P$. campechiana leaf and fruit extract when compared to the untreated cells. Metformin-treated cells showed the highest cellular uptake of 2-NBDG as shown in Fig. 4, 5 and 6. 

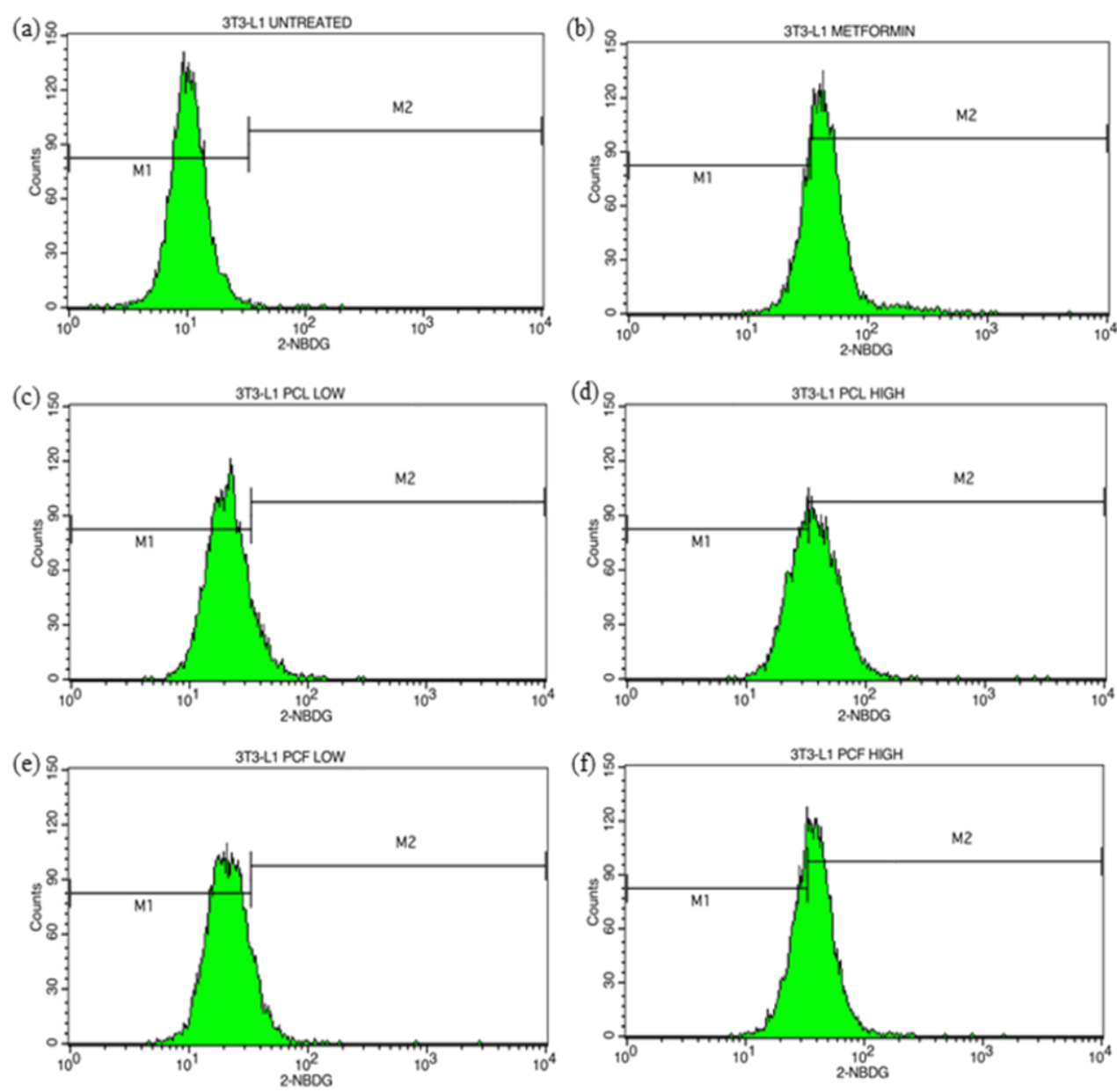

Fig. 4: Histograms showing the percentage uptake of 2-NBDG. a) Glucose uptake in control or untreated sample b) Glucose uptake in 3T3-L1 Cell line in standard drug, Metformin $(100 \mu \mathrm{M})$ treated c) Glucose uptake in 3T3-L1 Cell in PCL (40 $\mu \mathrm{g} / \mathrm{ml})$ treated d) Glucose uptake in 3T3-L1 Cell in PCL $(320 \mu \mathrm{g} / \mathrm{ml})$ treated e) Glucose uptake in 3T3-L1 Cell PCF (40 $\mu \mathrm{g} / \mathrm{ml})$ treated f) Glucose uptake in 3T3-L1 Cell in PCF $(320 \mu \mathrm{g} / \mathrm{ml})$ treated.

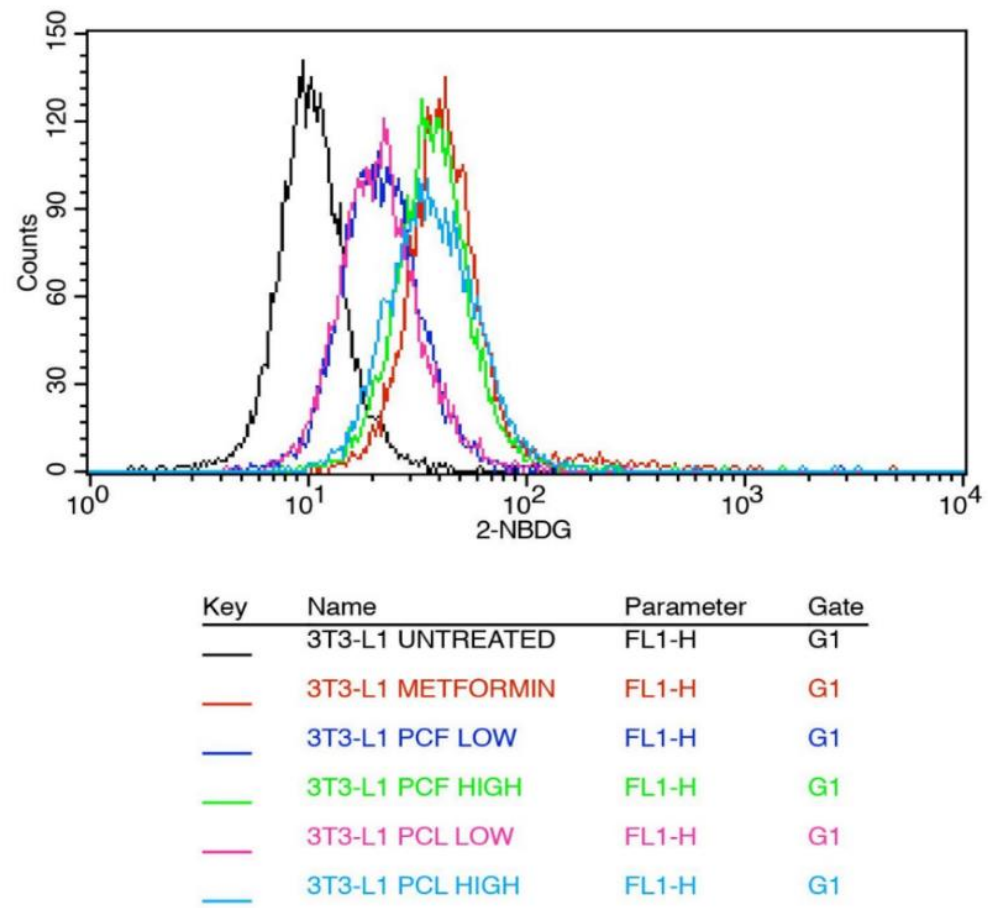

Fig. 5: Overlaid fluorescence intensities of given untreated 3T3-L1 cells (Black colour line) and Standard drug treated cells (Metformin $100 \mu \mathrm{M}$, Red colour line) and $40 \mu \mathrm{g} / \mathrm{ml}$ (Blue) and $320 \mu \mathrm{g} / \mathrm{ml}$ (Green) of P. campechiana fruit extract treated cells and $40 \mu \mathrm{g} / \mathrm{ml}$ (Pink) and $320 \mu \mathrm{g} / \mathrm{ml}$ (Light Blue) of $P$. campechiana leaf extract treated cells. 


\section{2-NBDG Uptake}

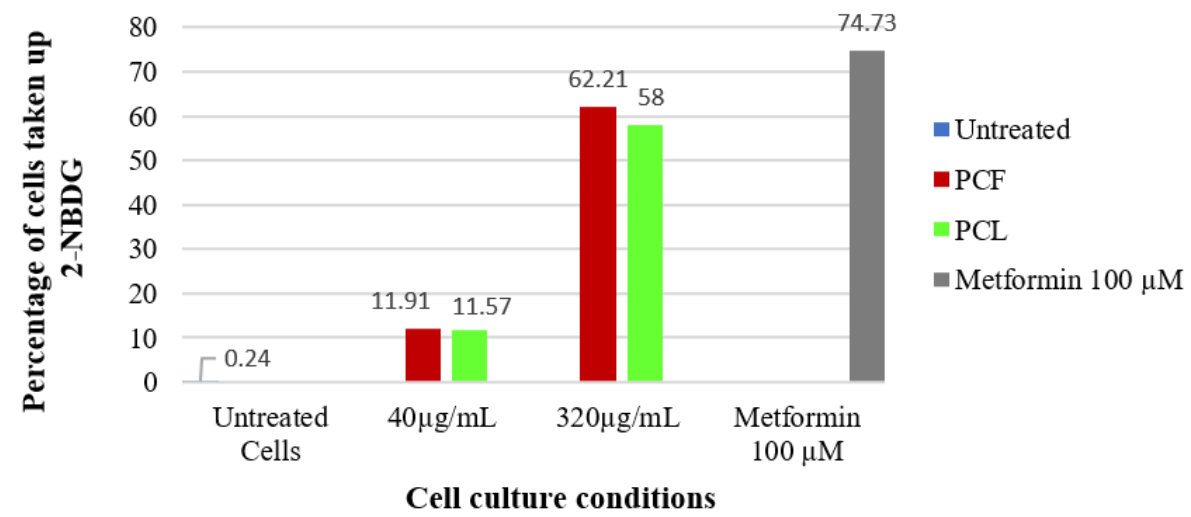

Fig. 6: Each bar graph represents the percentage of cells taken up the 2-(N-(7-nitrobenz-2-oxa-1,3-diazol-4-yl) amino)-2deoxyglucose in the presence of $40 \mu \mathrm{g} / \mathrm{ml}, 320 \mu \mathrm{g} / \mathrm{ml}$ of $P$. campechiana leaf and fruit extract and Standard drug Metformin $(100 \mu \mathrm{M})$.

\section{DISCUSSION}

Adipocyte differentiation inhibitors may be effective in preventing various diseased conditions such as obesity, atherosclerosis, diabetes and other associated complications. Under the appropriate conditions, 3T3L1 cells are known to differentiate into adipocytes and used as a model for adipose cells, which are one of the major sites of lipid and glucose metabolism (12). One of the approaches in tackling DM has been the use of agents that inhibit the action of enzymes involved in the absorption and metabolism of carbohydrates. The major enzymes involved in the absorption of glucose from the gut include the pancreatic $\alpha$-amylase and $\alpha$-glucosidase enzymes (13). Inhibition of these enzymes regulate the postprandial blood sugar level in Type 2 DM patients by reducing the absorption of sugars from gut. Existent antidiabetic drugs that specifically inhibit the activity of enzymes include acarbose, voglibose and miglitol. However, usage of these drugs can have adverse effects such as flatulence and abdominal bloating. Natural compounds from ethnomedicinal plants that do not have such effects are candidates of interest in the treatment of Type 2 diabetes. Such medicinal plants play a vital role in herbal medicine, particularly in treating ailments like diabetes (14).

The decrease in glucose uptake in type 2 diabetes is due to the insulin resistance developed by the cells. A fluorescent deoxyglucose analog, 2- (N-(7-Nitrobenz2-oxa-1,3-diazol-4-yl) Amino (-2-Deoxy glucose)) (2NBDG) used as a probe for the detection of glucose taken up by cultured 3T3 L1 cells. It is transported by both SGLTs and GLUTs and has allowed the study of the effects of drugs targeting glucose uptake and glycolysis (15). In this study, experiments on cellular uptake of glucose revealed that $P$. campechiana has the capability to induce glucose utilization by $3 \mathrm{~T} 3 \mathrm{~L} 1$ cells. After incubation of cells with $40 \mu \mathrm{g} / \mathrm{ml}$ and 320 $\mu \mathrm{g} / \mathrm{ml}$ of PCL and PCF extract for $2 \mathrm{~h}$ at $37^{\circ} \mathrm{C}$, 2NBDG uptake was observed in $11.91 \%, 62.21 \%$,
$11.57 \%$ and $58 \%$ of cells respectively, whereas it was observed in $74.73 \%$ of cells in the presence of $100 \mu \mathrm{M}$ of the standard drug, metformin and increased when compared to cell control as indicated in figure 6 .

The present study evaluated the antidiabetic properties of $P$. campechiana and results indicate that the methanolic extract of PCL and PCF effectively inhibits $\alpha$-amylase and $\alpha$-glucosidase activities. These inhibitory effects were estimated with acarbose as the standard drug. Furthermore, P. campechiana had no cytotoxic effect and we have proven the anti-diabetic activity of methanolic extract of $P$. campechiana in an in vitro cell-based model. However, further studies need to be carried out to understand the exact mechanism of action.

\section{CONCLUSION}

This novel study reports the antidiabetic properties of $P$. campechiana leaf and fruit as evidenced by biochemical assays and in vitro cellular assay. Methanolic extract of PCL and PCF extract showed no inherent cytotoxicity in 3T3-L1 cell lines tested, with IC50 values > $100 \mu \mathrm{g} / \mathrm{ml}$. PCL and PCF extract effectively inhibited the activity of the enzymes $\alpha$-amylase and $\alpha$-glucosidase, enhanced glucose uptake in 3T3-L1 cells. These results were comparable to the action of acarbose and metformin. This suggests that $P$. campechiana leaf and fruit has potential antidiabetic properties and may serve as a source of lead molecules possessing potential uses in the treatment of DM. However, further studies to identify and characterize these bioactive constituents must be performed.

\section{ACKNOWLEDGEMENT}

The authors acknowledge the Department of Biosciences, Mangalore University, for providing DST-FIST and UGC-SAP supported laboratory facilities. The authors wish to acknowledge the Council of Scientific and Industrial Research 
University Grants Commission (CSIR-UGC), New Delhi, for financial assistance.

\section{CONFLICT OF INTEREST}

The authors declare no conflict of interest.

\section{REFERENCES}

1. Alsawalha, M., Al-Subaei, A. M., Al-Jindan, R. Y., Bolla, S. R., Sen, D., Balakrishna, J. P., et al., Anti-diabetic activities of Dactylorhiza hatagirea leaf extract in 3T3-L1 cell line model. Pharmacognosy Magazine. 2019; 15(64): 212-217.

2. DeFronzo, R. A., Ferrannini, E., Groop, L., Henry, R. R., Herman, W. H., Holst, J. J., Weiss, R., et al., Type 2 diabetes mellitus. Nature Reviews Disease Primers. 2015; 1: 1- 22.

3. Ma, J., Yang, H., Basile, M. J., and Kennelly, E. J. Analysis of polyphenolic antioxidants from the fruits of three pouteria species by selected ion monitoring liquid chromatography-mass spectrometry. Journal of Agricultural and Food Chemistry. 2004; 52(19): 5873-5878.

4. Pai, A., \& Shenoy, C. Physicochemical, phytochemical, and GC-MS analysis of leaf and fruit of Pouteria campechiana (Kunth) Baehni. Journal of Applied Biology and Biotechnology. 2020; 8(04): 90-97.

5. Elsayed, A. M., El-Tanbouly, N. D., Moustafa, S. F., Abdou, R.M. \& ElAwdan, S. A. W. Chemical composition and biological activities of Pouteria campechiana (Kunth) Baehni. Journal of Medicinal Plants Research. 2016; 10(16): 209-215.

6. Agu, K. C., Eluehike, N., Ofeimun, R. O., Abile, D., Ideho, G., Ogedengbe, M. O., et al., Possible anti-diabetic potentials of Annona muricata (soursop): inhibition of $\alpha$-amylase and $\alpha-$ glucosidase activities. Clinical Phytoscience. 2019; 5(21): 113.

7. Thilagam, E., Parimaladevi, B., Kumarappan, C., Chandra Mandal, S. $\alpha$-glucosidase and $\alpha$-amylase inhibitory activity of Senna Surattensis. Journal of Acupuncture and Meridian Studies. 2013; 6(1): 24-30.

8. Kumar, A. B. S., Lakshman, K., Jayaveera, K.N., Shekar, S.D., Swamy, N.V.B., Khan, S., Velumurga, C. In vitro $\alpha-$ amylase inhibition and antioxidant activities of methanolic extract of Amaranthus caudatus Linn. Oman Medical Journal. 2011; 26(3): 166-170.

9. Dayananda, K. S., Reddy, J.M.P., Ajaymandal. Inhibitory effect of a polyherbal formulation on $\alpha$-glucosidase, and porcine pancreatic amylase in type ii-diabetes. World Journal of Pharmaceutical Research. 2015; 4(4): 438-447.

10. Mosmann, T., Rapid colorimetric assay for cellular growth and survival: application to proliferation and cytotoxicity assays. Journal of Immunological Methods. 1983; 65: 55-63.

11. Alsawalha, M., Al-Subaie, A. M., Al-Jindan, R. Y., Bolla, S. R., Balakrishna, J. P., Ravi, P. K., et al., Effect of Litsea lancifolia leaf extract on glucose transporter 4 translocation and glucose uptake in 3T3L1 cell line. Journal of Pharmacy \& Bioallied Sciences. 2019; 11: 240-7

12. Prathapan, A., Mahesh, K. S., Lekshmi, P., Raghu, K. G., \& Menon, A. Modulation of adipogenesis and glucose uptake by Curcuma longa extract in 3T3L1 and L6 cell lines -an in vitro study. Asian Pacific Journal of Tropical Disease. 2012; 2(1): 163-165.

13. Kajaria, D., Tiwari, S., Tripathi, J., Tripathi, Y., \& Ranjana. In-vitro $\alpha$-amylase and $\alpha$-glycosidase inhibitory effect of ethanolic extract of antiasthmatic drug - shirishadi. Journal of Advanced Pharmaceutical Technology \& Research. 2013; 4(4): 206-209.

14. Alsawalha, M., Al-Subaie, A. M., Al-Jindan, R. Y., Bolla, S. R., Balakrishna, J. P., Ravi, P. K., et al., Effect of Litsea lancifolia leaf extract on glucose transporter 4 translocation and glucose uptake in 3T3L1 cell line. Journal of Pharmacy and Bioallied Sciences. 2019; 11: 240-247.

15. Dubey, S., Mishra, D. K., Acharya, A., Dubey, S., \& Bole, S. Study of glucose uptake activity of Aegle marmelos ethanolic extract on liver cell line by flow cytometry. World Journal of Pharmacy and Pharmaceutical Sciences. 2018; 7(6): 12421247. 